\title{
Sustainability Subjects in University Education - Development of a Comprehensive Indicator System and Quantitative Analysis of Degree Programs at German Universities
}

\author{
Eckard Helmers ${ }^{1 *}$, Fabienne Ilchmann ${ }^{1}$ \\ ${ }^{1}$ Environmental Planning and Technology Department, Trier University of Applied Sciences, Umwelt-Campus Birkenfeld, \\ PO box 13 80, 55761 Birkenfeld, GERMANY
}

\section{*Corresponding Author: e.helmers@umwelt-campus.de}

Citation: Helmers, E. and Ilchmann, F. (2019). Sustainability Subjects in University Education Development of a Comprehensive Indicator System and Quantitative Analysis of Degree Programs at German Universities. European Journal of Sustainable Development Research, 3(4), em0092. https://doi.org/10.29333/ejosdr/5771

Published: May 11, 2019

\begin{abstract}
A new comprehensive evaluation system presented here allows to compare and to quantify education for a sustainable development (ESD) in degree programs. The evaluation is based on a criteria system working with three hierarchic levels. The highest level considers a list of 35 indicator terms. Primarily, the two most popular undergraduate (bachelor's) degree programs in Germany (mechanical engineering, ME, and business administration, BA) have been reviewed for ESD contents based on the new evaluation scheme. Additionally we reviewed and quantified ESD subjects and their temporal changes in the entire bandwidth of degree programs of a university (Umwelt-Campus Birkenfeld, University of Applied Sciences Trier), back to 1999. Moreover, a spot check on international ME and BA bachelor's degree programs was performed. Through our reviews, we found a high number of elective classes dedicated to ESD particularly in BA bachelor programs. However, the percentage of compulsory classes related to ESD is relatively low with 5$6 \%$ in both $\mathrm{ME}$ and $\mathrm{BA}$ programs, respectively. The spot check on degree programs outside Germany revealed similar results. Analysing the time trend at Umwelt-Campus Birkenfeld, a considerable share of ESD that was part of the original diploma degrees was moved to what are now master's degrees.
\end{abstract}

Keywords: higher education for a sustainable development, ESD, sustainability education, indicator system, time trend, Umwelt-Campus Birkenfeld, bachelor degree programs in business administration and mechanical engineering

\section{INTRODUCTION}

\section{Sustainability Education}

Sustainability education or, more specifically, "higher education for a sustainable development" (Adomßent et al., 2014), shortened to ESD (education for a sustainable development), is according to its UNESCO definition " $a$ learning process or approach to teaching based on the ideals and principles that underlie sustainability and is concerned with all levels and types of learning to provide quality education and foster sustainable human development' (cited in Disterheft et al 2013). It emerged as a topic during the United Nations Conference on Environment and Development in Rio de Janeiro (1992) and was institutionalized as part of the "Agenda 21" which was adopted on the same conference (Disterheft et al 2013). Its institutionalization resulted in the UN Decade of Education for Sustainable Development 2005 - 2014 (e.g.: UNESCO, 2005; Wals, 2014) and in the UNESCO Global Action Programme on ESD launched in 2014 
(UNESCO, 2018). A full chronological listing of global milestones leading to international ESD activities is provided by Disterheft et al. (2013). Karatzoglou (2013) published an overview on roles and contributions of universities to push ESD pointing to a leading role of European universities. The concept of ESD has been translated to specific areas of studies, such as management (Godeman et al., 2014).

ESD activities were also institutionally addressed on a national level. The German UNESCO commission, for example, coordinates activities nationally, such as the adoption of a German national action plan on ESD (UNESCO Germany, 2018). Additionally, universities focussed on sustainable institutional management have undertaken activities such as the "university-specific sustainability codex", which however only made marginal references to ESD (German Council for Sustainable Development, 2018).

Today, 27 years after the Rio conference, the question arises which role ESD currently takes in everyday university education.

\section{Motivation for this Study}

The motivation for this work developed during the unfolding of the "diesel scandal" (Archer, 2016) in Europe and the U.S.A. In 2015 it was made public that millions of diesel cars used so-called "defeat devices" (Degraeuwe and Weiss, 2017), which prevent realistic emissions measurement of the vehicles on a dynamometer (test stand) and instead report false lower emissions. To achieve this, quite a number of university trained engineers must have worked together to develop a set of highly sophisticated technologies, not to minimize emissions into the environment, but instead to cheat the environment, customers, and the governments. University trained experts seem to have invested their intellect into the development of an apparently unethical device. The reasons for this industry scandal will be complex, however, the following question arises: May there simply be knowledge gaps, when it comes to the impact of toxic emissions on health and environment? Engineering courses at universities, this is the starting hypothesis, backed by 20 years of personal teaching experience, can be little interdisciplinary and lacking environmentally related subjects such as environmental chemistry and toxicology. Such knowledge, however, would be indispensable to distinguish between more and less (un)favourable technological options. The problem is highlighted by a campaign launched in Germany in 2017 to counteract the public irritation about the continuing emission cheating, and claiming that the EU/WHO threshold of $40 \mu \mathrm{g} \mathrm{NO} / 2 \mathrm{~m}^{3}$ is inappropriately low when compared to the maximum concentration of $950 \mu \mathrm{g} \mathrm{NO} / \mathrm{m}^{3}$ which is allowed at working places. It was a campaign lacking fundamental insight into the basics of environmental and health protection and the emergence of such thresholds (Umweltbundesamt, 2018), perhaps not because of a spirit of mischief, but simply due to lack of knowledge. These recent social developments specifically confirmed the need for interdisciplinary education related to sustainability subjects.

Prior to diagnosing a possible need to widen interdisciplinary and sustainability-related university education, the status quo needs to be quantified. It is the objective of this study to suggest a methodology able to achieve such a quantification and to provide an analysis covering two important university disciplines.

\section{MATERIALS AND METHODS}

\section{ESD Keywords and Development of a Criteria System}

This is not a paper dealing with the question of how to organize ESD to achieve optimized learning efficiency for the students (e.g. Figueiro and Raufflet, 2015). Instead it is a project trying to provide a comprehensive approach of quantifying ESD in degree programs in order to generate a fundamental assessment about how much ESD has been integrated so far into academic teaching. Such quantitative analyses seems to be missing currently.

Indicator systems assessing sustainability achievements have already been used in ESD research, however they are usually based on a qualitative "Yes/No" decision matrix (e.g. Jones et al., 2008; Siemer et al., 2006) or are part of a larger evaluation system focussing on university management aspects (Berzosa et al., 2017; Holm et al., 2015; Togo and Lotz-Sisitka, 2009). Stough et al. (2018) provided a quantitative assessment of many sustainability-related keywords appearing in degree programs at Catholic University of Leuven, but without a quantitative comparison of degree programs. All in all, indicator systems available so far are much more restricted in keywords (e.g. 18 criteria and indicators analysed by Khalili et al., 2015) than the one presented in this work. Another ESD study is based on a questionnaire and evaluates answers received from universities worldwide (Lozano et al., 2015).

Any quantitative assessment of the ESD status would ideally require a comprehensive list of topics and keywords which may be covered in ESD. However, the definition of the term sustainability itself is complex (Glavič and Lukman, 2007), as is the history of sustainability (Caradonna, 2014) which may lead to the conclusion that an identification of sustainability related contents in education might be very complex or even impossible. Fortunately, the institutional history of sustainability, particularly on UN level, led to a limited number of generic terms. These terms were collected in level A, complemented by general terms plus further essential sustainability indicators we 
Table 1. Indicator and criteria system to identify ESD. German translations provided as these terms were used for quantification of ESD in German language classes

\begin{tabular}{|c|c|c|}
\hline Indicator level & Indicator items & (German translation) \\
\hline \multirow{6}{*}{$\begin{array}{l}\text { A } \\
\text { Academic classes } \\
\text { specifying } \\
\text { sustainability } \\
\text { aspects in title or in } \\
\text { module description }\end{array}$} & \multicolumn{2}{|c|}{ A-I general terms (adjectives) indicating sustainability aspects } \\
\hline & $\begin{array}{l}\text { transformation, environmental, sustainable, global, } \\
\text { resources, eco- }\end{array}$ & $\begin{array}{l}\text { Transformation(s-), Umwelt-, nachhaltige .., } \\
\text { Nachhaltigkeits-, globale .., Ressourcen-, } \\
\text { zukunftsfähig .., Öko- }\end{array}$ \\
\hline & \multicolumn{2}{|l|}{ A-II UNECE (2006) indicators } \\
\hline & $\begin{array}{l}\text { peace studies, ethics and philosophy, citizenship } \\
\text { (democracy and governance), human rights, } \\
\text { poverty alleviation, cultural diversity, biological and } \\
\text { landscape diversity, environmental protection, } \\
\text { ecological principles/ecosystem approach, natural } \\
\text { resource management, climate change, personal } \\
\text { and family health, environmental health (pollution), } \\
\text { corporate social responsibility, production and/or } \\
\text { consumption patterns, economics, rural/urban } \\
\text { development }\end{array}$ & $\begin{array}{l}\text { Friedensstudien, Ethik und Philosophie, } \\
\text { Staatsbürgerkunde, Menschenrechte, } \\
\text { Armutsbekämpfung, Kulturelle Diversität, } \\
\text { Biologie (wenn Schutz der biologischen und } \\
\text { Landschaftsdiversität), Umweltschutz, Ökologie, } \\
\text { Management natürlicher Ressourcen, Klimawandel } \\
\text { (,global change”), Gesundheit (Management) und } \\
\text { Epidemiologie, soziale Unternehmens- } \\
\text { verantwortung, Konsumverhalten, } \\
\text { Volkswirtschaftskunde, Städte- und } \\
\text { Umweltplanung (i.e.S.). }\end{array}$ \\
\hline & \multicolumn{2}{|c|}{ A-III amendments from the 17 sustainable development goals (UN, 2018) } \\
\hline & $\begin{array}{l}\text { zero hunger (diet, sustainable agriculture, food } \\
\text { production), gender equality, protection of water } \\
\text { resources and the aquatic environment, renewable } \\
\text { energies, infrastructure (mobility), social equity, } \\
\text { occupational safety }\end{array}$ & $\begin{array}{l}\text { Ernährung (weltweit, nachhaltige Landwirtschaft, } \\
\text { Nahrungsmittelproduktion), Gender } \\
\text { (Geschlechterstudien), (Schutz der) Wasser- } \\
\text { ressourcen und der aquatischen Umwelt, } \\
\text { Erneuerbare Energien, Infrastruktur (Mobilität), } \\
\text { soziale Gerechtigkeit, Arbeitssicherheit }\end{array}$ \\
\hline
\end{tabular}

A-IV guideline of "Learning to live \& work together" (UNECE, 2006) \& participation (Haan and Harenberg, 1999)

communication, conflict management, and Kommunikation, Konfliktmanagement \& mediation Mediation

A-V risk perception and quantification (UNESCO, 2011, 2012)

Life cycle assessment, technology and risk Ökobilanzierung, Technikfolgen- und assessment

Risikoabschätzung

B Which parts of a degree program are from outside the core topic(s)?

Interdisciplinarity (in addition to the above keywords, but to decide individually).

Training in foreign languages included.

C Institutionalized international elements in a degree program

Internationalisation (foreign guest semesters and internships, international co-operation in degree programs, subject classes given in foreign languages)

A1, B1, C1=compulsory. A2, B2, C2=elective

identified in the literature. This way 35 search items (indicators) were collected in level A. They are complemented by two further categories $(\mathrm{B}, \mathrm{C})$. We ended up with a hierarchic three-level set of keywords and criteria (Table 1) characterising ESD which we structured as follows in levels A-C:

\section{Level A:}

First of all, we were looking for general terms in module titles and descriptions pointing to sustainability topics addressed, which are "transformation", “environmental”, "sustainable", "global”,"resources"," eco-" (Table 1, AI).

A UNECE expert group on indicators for ESD has defined a core list of 17 topics related to sustainability in education (UNECE, 2006), ranging from peace studies to rural/urban development (Table 1, A-II).

As a third step, we visited the currently valid 17 fundamental SDG's (sustainable development goals) of the United Nations (UN, 2018) examining these for gaps not covered by the above enumeration. We interpreted the SDG's resulting in the following list of additional sustainability topics: zero hunger (diet, sustainable agriculture, food production), gender equality, protection of water resources and the aquatic environment, renewable energies, infrastructure (mobility), social equity, occupational safety (Table 1, A-III).

We then searched the ESD literature for further fundamental key-qualifications complementary to the indicators listed above identifying further essentials amendments. UNECE (2006) describes an area of "Learning to live and work together", specified with the terms "acting with responsibility", "collaboration/team working", "participation", and "negotiation and consensus building". Haan and Harenberg (1999) condense that in saying "Participation is a central guiding principle of the Agenda process" (translated from German). We substantiate this to the (more common) education area of communication, conflict management, and mediation (Table 1, A-IV). 
One last area that is emphasised in the literature as a core competence is risk perception and quantification (UNESCO, 2011, 2012). We translate it into the topics of life cycle assessment, technology and risk assessment, all of which can be found in university education (Table $1, \mathrm{~A}-\mathrm{V}$ ), therewith completing the indicators described in level A (Table 1). Altogether, the result is a comprehensive list of 35 indicator terms (some of them complex terms) which does however not exclude future amendments.

\section{Level B:}

We further established a fundamental indicator category (B) defining the need of interdisciplinarity in ESD. Haan and Haarenberg (1999) clearly formulated: "Interdisciplinarity is (the) conditio sine qua non in the discourse on ESD". Like Haan and Haarenberg (1999), we regard this as being one of the fundamental problems in today's university education when it comes to the tackling of current environmental problems: the lack of interdisciplinarity (see motivation above). Dalrymple and Miller (2006) described "interdisciplinarity as "a key for real-world learning", mostly related to environmental problems.

The identification of potential gaps in interdisciplinarity, however, is difficult. On the one hand, curricula in disciplines like engineering have, at least in Germany, a high degree of similarity when comparing different universities. This can be traced back to former frame regulations specifying the essential classes, which was passed by "The Standing Conference of the Ministers of Education and Cultural Affairs of the Länder in the Federal Republic of Germany" (KMK, 2018). This system was replaced in 2002 by an accreditation system which continued to ensure comparability of the most common degree programs (KMK, 2018), including the two programs we analyzed: Mechanical engineering and business administration. These regulations allow, as for example, to identify classes seen as fundamental in an engineering curriculum. Additionally, students usually can select courses out of a variety of specialized engineering subjects. These are not interdisciplinary, but represent professional specialization and immersion into of the main subject. A class, however, scored here as an additional interdisciplinary subject of the curriculum needs to be a completion from a different, usually independent scientific subject.

An application of the indicator section B on degree programs which are fundamentally interdisciplinary (like e.g. "International Material Flow management", see http://www.imat-master.com/), is not possible, which means classes of such a degree program would not score additional ESD percentages in section B (exemption: interdisciplinary excursions, as in the degree program Sustainable Change (b12 in Figure 4).

Training in foreign languages is, of course, usually outside the core subjects of a certain discipline. It is important to consider, that language proficiency is regarded as being a core element (UNESCO, 2017) enabling intercultural competence (UNESCO, 2009, 2017). Cultural or language competence, in turn, is a prerequisite for the ability to participate on the international level of scientific or political discourse (Table 1, A-IV). With respect to the complex and interdisciplinary nature of common environmental problems such as global warming, participation has to include the ability to follow the international scientific discussion. In this regard, English language competences possess highest priority because between $80 \%$ (Weijen, 2012) and in some disciplines more than $90 \%$ (Scott, 2013) of all scientific communications worldwide are published in English. We count, however, all foreign language classes (not just English language) in the indicator section B as part of a degree program offered in Germany. Consequently, this criterion can also be applied on degree programs in English-speaking countries when offering training in foreign languages.

\section{Level C:}

We are living in the age of the Anthropocene, since 1945 facing "The great acceleration in Global Change" (Ellis, 2018). Current environmental and sustainability problems can only be tackled in international co-operation, particularly when it comes to the limitation of resources and to global warming (e.g. WBGU, 2011). Hence, every element of internationalisation in a degree program supports the ability of students in acting for a viable future of mankind. This way, internationalization of higher education would ideally lead to a "planetary citizenship education" seeking "a future sustainable in environmental, social and etbical terms" (Haigh, 2008). We therefore generate a third fundamental ESD category, called "internationalisation, level C” (Table 1). In our scheme, this category doesn't apply for degree programs fully given in a foreign language. In Table 1, we provide the German translations for the indicators we applied in testing degree programs of German universities.

\section{Further selection criterions and quantification}

We have organized the three categories A, B, C, in a hierarchic manner. We analyzed degree programs' classes first by matching the indicators in section $\mathrm{A}$, then in $\mathrm{B}$, at last in $\mathrm{C}$. If a class fits the categories of more than one level, then it is counted in the highest level. A further general classification is the mandatory vs. voluntary character of a curriculum subject: Whether all students are exposed to a certain topic or just those selecting a certain class offered, that can make a decisive difference in the average skills of graduates. A1, B1, C1 mark mandatory subjects of study, while A2, B2, and C2 classify voluntary classes in a degree program. With this scheme presented, similar degree programs from different universities can be compared to each other, but as well sets of degree programs of a university among themselves, with those of other universities, or alterations of curricula in time. 


\section{ESD Quantification in German University Degree Programs: Selecting the Fields of Study}

Within a given time frame, we wanted to gain the most representative overview of German university degree programs as possible. The most recent data on student enrolment available at the time of investigation (2017) were based on the autumn semester 2015/16 in Germany. In this semester there were 2.76 Mio students enrolled at 426 institutions of tertiary (higher) education in Germany (Statistisches Bundesamt 2016). Among these, there were 107 Universities $^{1}$ and 215 Universities of Applied Sciences ${ }^{1}$, which are the kind of institutions we wanted to cover. In the winter term 2015/16, $97.4 \%$ of all German students were enrolled at these two types of higher education institutions (Statistisches Bundesamt, 2016). Business administration (BA 2 , in German: Betriebswirtschaftslehre) and Mechanical Engineering (ME, in German: Maschinenbau) were the leading degree program areas with $8 \%$ and $4 \%$, respectively, of all students enrolled (Statistisches Bundesamt, 2016). When it comes to the partitioning between bachelor and master students, in the BA study area $77 \%$ were bachelor students in 2015/16, whereas 69 $\%$ of the ME students were bachelor students (Statistisches Bundesamt, 2016), respectively. Following these statistical data we decided to assess German bachelor degree programs in BA and ME for ESD contents. We then decided to analyse as many individual degree programs as necessary to cover at least $1 / 4$ of all students enrolled, which were 45,352 students in the bachelor of BA (equivalent to $25.1 \%$ of all enrolled in BA bachelor programs, at Universities and Universities of Applied Sciences together). The degree programs of 31,078 students in the bachelor of ME, on the other hand, have been considered for ESD analysis, which is equivalent to $37.7 \%$ of all students enrolled in the winter term 2015/16 (calculated from Statistisches Bundesamt 2016, Universities and Universities of Applied Sciences taken together). The percentage of coverage in the bachelor of ME is higher due to the fact that the bigger institutions collect a higher share of students. We considered more than $1 / 4$ of the students enrolled in ME because this way we were able to assess an equivalent numbers of Universities and Universities of Applied Sciences each. Generally, we were systematically looking for analysing the degree programs with the biggest number of enrolments first and followed by the smaller ones until at least $1 / 4$ of all students nationwide in the respective degree programs are considered.

\section{Transformative Significance of BA and ME Bachelor Programs}

These two degree programs are not only the most popular ones among German students, but the graduates will play an essential, if not the most important role when it comes to tackling future challenges of global change: Engineers are developing the technologies of the future which need to be much smarter than today's technology with less emissions and resources consumption - this is why engineers should be familiar with methods such as Life Cycle Assessment, which is seen as a new sustainability subject in engineering education (Ramos et al., 2015).

Engineers who are trained to identify and work out efficient technical solutions would urgently need to expand their traditional understanding of "efficiency" (traditionally in terms of material and energy efficiency) towards the environmental and health costs of technical alternatives. Although there is already a trend towards more interdisciplinary education in engineering (Klaassen, 2018), the question arises how much of it already arrived to the traditionally rather "closed-off" world of engineering education, which is quite mono-disciplinary and assumes that graduates will work as specialists (Harrison et al., 2007). Mulder (2017) complains that "the strategic sustainable development paradigm" is generally missing in engineering education. Economists, on the other hand, need to develop the business models necessary to spread smarter technologies and management approaches in a sustainable way. One of those approaches is, for example, the enhancement of regional material flow management and zero emission strategies (Helling, 2018). Ideally, ideas like these should be included in the education of economists.

A Google scholar research (2018) for "interdisciplinary education in business administration" reveals more than twice the number of results compared to searching the keywords "interdisciplinary education in mechanical engineering" implying that the field of BA may be more open to inputs from other disciplines. By contrast, hochschulkompass.de (2018) delivers a comparable number of German degree programs in both the sectors of $\mathrm{BA}$ and ME with an emphasis on "environment" implying similar sustainability interests in both academic areas. We are, however, assessing basic degree programs in BA and ME, not those specifically addressing environmental problems.

\footnotetext{
${ }^{1}$ In Germany there are two leading types of higher education institutions: The so called "full universities" are referred to here as

"universities", different to the "Universities of Applied Sciences".

${ }^{2}$ Note: BA is used as abbreviation for "Business Administration" in this text. The term "bachelor", on contrary, is always written out.
} 
Table 2. Sequential assessment scheme when analysing German ME and BA bachelor study programs. All investigations applied on documents which were publicly available in the internet. *) see Table 1

1) Verification whether the investigated degree program is available at a university

$\downarrow$

2) Verification whether the number of students enrolled is available in university documents (only in case of a study guideline in student $\rightarrow$ if not, switch to next university enrolment representativity)

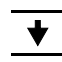

3) Verification whether curriculum details and/or handbook of modules available

if not, switch to next university

4) Verifying titles of classes for indicator terms; level A*

if not, switch to next university

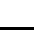

if found, quantify impact as long as possible by title. If quantification is not possible by title, and if indicator terms not found in title, check handbook

5) Inspecting titles of classes for interdisciplinary topics, level B*

in case of uncertainty, check handbook

6) Verifying the curriculum for institutionalized international elements, level C*

in case of uncertainty, check handbook

\section{ESD Quantification: Detailed Strategy}

The chosen university degree programs are assessed following the general scheme depicted in Table 2 . Furthermore, the quantification is accomplished by some more rules which were developed to reach reproducibility and comparability of this quantification scheme:

a) Generally it is differentiated between mandatory (sublevel 1) and elective (sublevel 2) classes (A1, B1, C1: mandatory; A2, B2 C2: electives)

b) In case a sustainability term is identified in the full title of a class, this class is scored to the respective level by $100 \%$. In case only one indicative subject is mentioned in the title of a class next to another, not indicative subject, only $50 \%$ of the class is scored to the respective level. This is applied accordingly while scoring the module descriptions in the handbook.

c) Following the previous step, we quantified the affiliation to an indicator level/sublevel by quarters of 100 $\%: 0 \%, 25 \%, 50 \%$, or $100 \%$, a scheme which was also applied by Togo and Lotz-Sisitka (2009). We believe with respect to the common heterogeneity of module descriptions, that a more detailed quantification would imply an unrealistic precision. Sustainability proportions smaller than $25 \%$ were not considered.

d) We multiplied the percentages derived this way with the number of ECTS points given in the module description considering this way the significance of a single class relative to the whole degree program. We then added up the ECTS points in all sub-/levels relative to the maximum number of ECTS in the degree program (in Germany usually 180 ECTS in a 3-year bachelor's degree). This way we were able to quantify the size of the nonsustainable share of the degree program as well.

e) Some degree programs offer students a large variety of electives. Because it is impossible to display all combinations, we were considering the option with the highest score only.

f) International universities: At some international universities outside Europe (and even at some British Universities) the ECTS scheme is not available. Additionally, the academic year can be organized differently to the German scheme which is based on two semesters/year: However, in a trimester system like at the University of Cambridge one semester is associated with the equivalent of 20 ECTS (Cambridge University, 2018) which sums up to 60 ECTS/year, as it is usual in Europe. In cases the ECTS scheme is not operated, universities commonly apply another unit system similar to ECTS (as e.g., the Scottish Credit \& Qualification Framework, the Singapore Modular Credits), which is then utilized accordingly here.

g) Some curricular elements don't allow any quantification of their sustainability level because no general assessment is possible: the thesis, seminars for scientific writing and practical elements such as internships in industry. They were excluded and (ECTS) points allocated to these curricular elements were subtracted from the maximum number of ECTS in the respective degree program. 


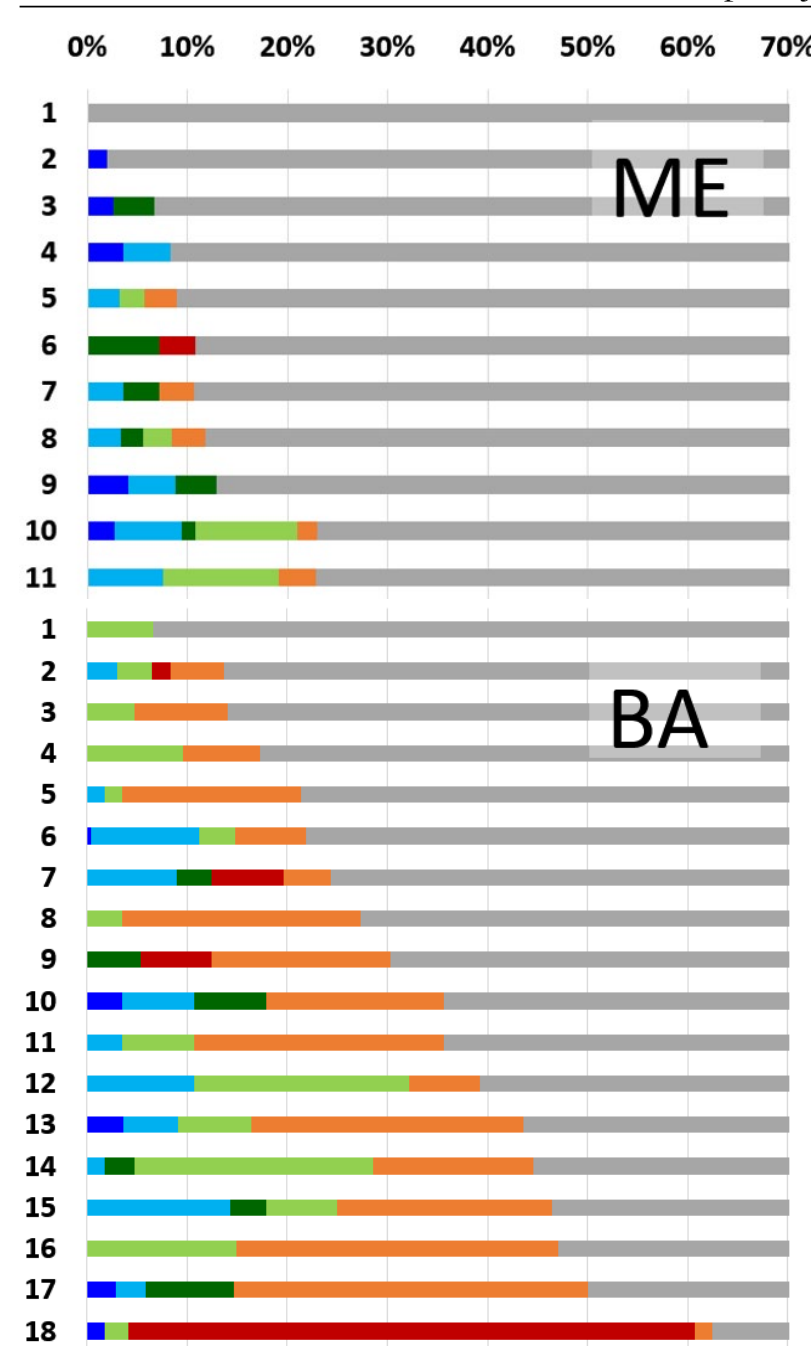

Universities
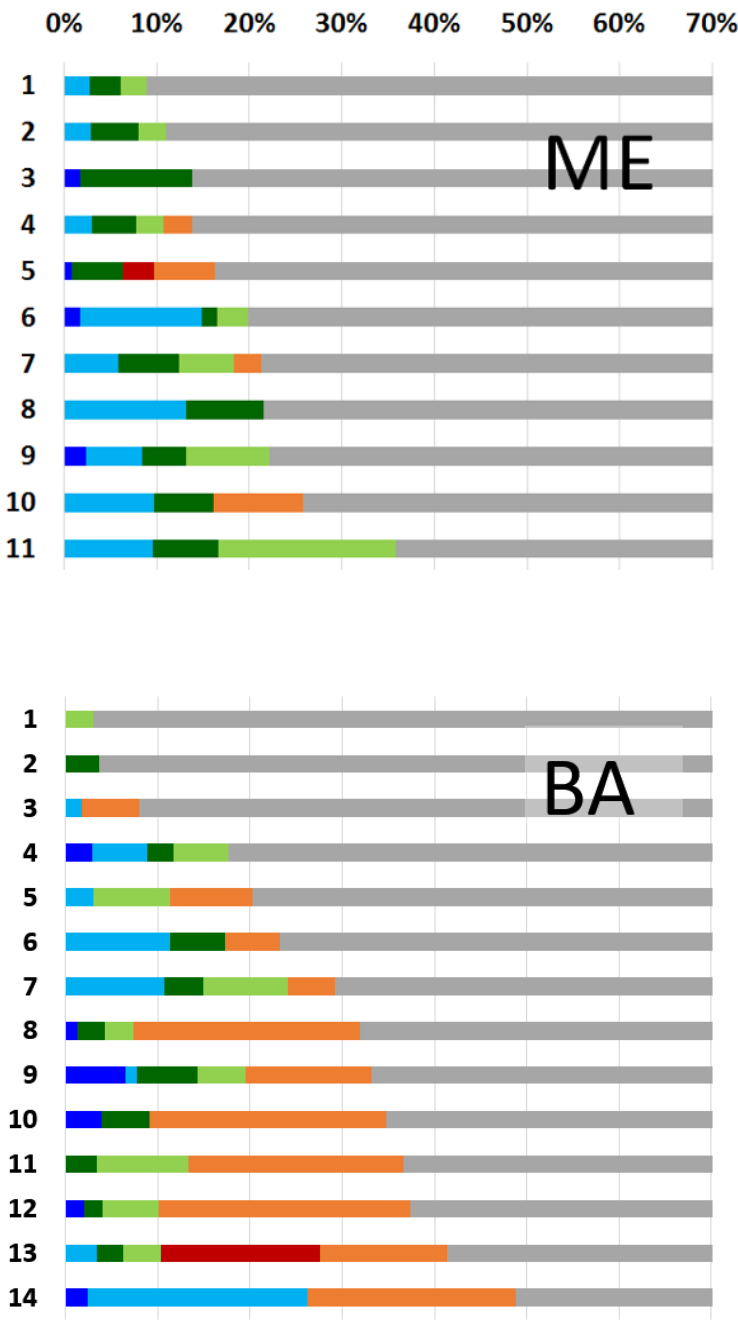

Universities of Applied Sciences

$\square \mathrm{A} 1 \square \mathrm{A2} \square \mathrm{B1} \square \mathrm{B2} \square \mathrm{C1} \square \mathrm{C2} \square$ no ESD

Figure 1. Quantification of ESD (\%) in curricula of German universities and universities of Applied Sciences in the bachelor degree programs of mechanical engineering (ME) and business administration (BA). Data refer to information valid for winter term 2017/18. The selected institutions have the highest number of enrolments nationwide in the respective degree programs. Sorted by ascending numbers (totals). The indicators A1-C2 refer to Table 1. Examined universities are specified in the supplement Table S1. ESD = education for a sustainable development

\section{RESULTS AND DISCUSSION}

\section{German Bachelor's Degree Programs in ME and BA}

The main investigation assesses degree programs at 22 Universities of both academic types offering ME as a bachelor as well as 32 education institutions offering BA programs (Figure 1), with both sets representing the institutions with the highest numbers of enrolments in the two degree programs in Germany (enrolment numbers see above). The number of students enrolled in each of these institutions was taken from internet pages of the respective University, partly from University/rectorate reports which were the most recent, each available at the time of investigation (October to December, 2017). Student enrolment numbers in ME at the individual institutions were particularly different, ranging from 7,621 students (Techn. University of Aachen) to 145 students (University of Applied Sciences Trier, Umwelt-Campus Birkenfeld).

Bachelor degree programs in BA were investigated at 14 Universities of Applied Sciences and 18 Universities in Germany, respectively (enrolment numbers see above). Student enrolment numbers for the bachelor in BA were ranging from 4,607 BA students at University of Münster to 582 students enrolled at Catholic University of Eichstätt-Ingolstadt. 


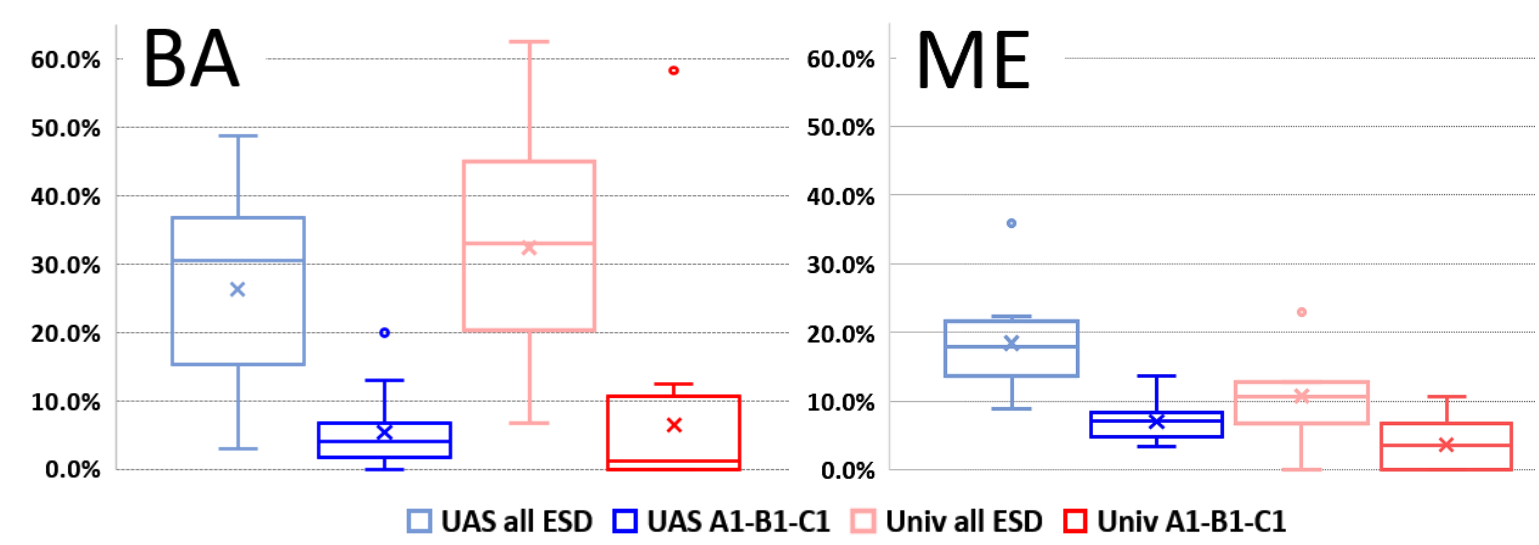

Figure 2. Boxplot analysis of ESD distribution (\%) at German universities based on the data shown in Figure 1. Dark colours: compulsory classes, light colours: all classes considered. $\mathrm{BA}=$ business administration, $\mathrm{ME}=$ mechanical engineering. UAS $=$ Universities of Applied Sciences. Univ $=$ Universities. The indicators A1-B1-C1 refer to Table 1. ,all” = indicators A1-C2. ESD = education for a sustainable development

Quantitative analysis of ESD in the respective degree programs (ME and BA) of German education institutions reveals high fluctuations: Results range from no ESD at all (ME, Technical University of Dortmund) to $62.5 \%$ at university of Mannheim (BA), the latter degree program dominated by modules taught in English language (Figure 1).

On average, it turned out BA programs contained roughly twice as much ESD compared to ME programs ( $29.4 \%$ vs. $15.0 \%$, Universities and Universities of Applied Sciences taken together). However most of it is offered in the form of elective classes. In ME degree programs, $9.6 \%$ of the ESD found is offered in elective classes (Figure 1). It means, in turn, that students passing ME degree programs will have a guaranteed minimum of just $5.4 \%$ of their lessons dealing with ESD, which is equivalent to approximately every $20^{\text {th }}$ hour in education.

The situation is similar in BA degree programs (Figure 2): Just $6 \%$ of the ESD detected is mandatory (Universities and Universities of Applied Sciences taken together). This is, however, shrinking to $4.2 \%$ in case the University of Mannheim is removed. More anomalous in this context is the relatively high amount of elective classes dealing with ESD in BA degree programs: $23.4 \%$ on average (Universities and Universities of Applied Sciences taken together). There is no general trend in the ESD percentages of Universities vs. the Universities of Applied Sciences: In the bachelor programs of ME, Universities of Applied Sciences offered significantly more ESD classes (19.2\%) compared to the Universities (10.7\%). This turned out to be the other way around when analyzing BA degree programs, but the difference is less notable (26.4\% vs. $32.2 \%$ ), compared to ME (Figure 2).

In conclusion, although the analysed BA degree programs offer a very high number of electives dealing with ESD (Figure 2, left) only a very small percentage of all students inevitably get in contact with ESD when unselecting ESD classes as much as possible (Figure 2). In this regard, there is no fundamental difference between $\mathrm{BA}$ and ME (Figure 2), as it is not between the two types of universities investigated.

\section{International Bachelor Degree Programs in ME and BA}

A spot check has been performed in order to compare bachelor degree programs in both ME and BA outside of Germany. This turned out to be complicated due to several reasons: First we were restricted to universities with full English language homepage documentation which limits such an investigation to English speaking countries and places with a particularly international atmosphere such as Singapore. Furthermore, outside Europe there are usually no single documents detailing all classes of a degree program including content descriptions as in the "Module handbooks" commonly used in Europe. We had to manually click through the online materials available, separately for all elements of the individual degree programs to review them. Outside Europe, the European Credit Transfer System (ECTS) is of course not valid either, which made a fast quantification of education elements within a degree program more difficult. Alternatively, all classes of a non-European degree program had to be quantified as being equal in effort and time consumption. While in Europe the Bologna system awards the bachelor's degree after 3 years of studying, the minimum time spent in a regular degree program in the US and other countries following the Anglo-American education tradition is 4 years. Because a U.S. bachelor's program in mechanical engineering could not be found, we had to opt for an Undergraduate Studies program in Mechanical Engineering at University of California, Berkeley, USA (Table S2). Facing the much higher variability in the status of academic institutions outside Europe, particularly in USA, we focussed on bigger, well known universities.

Nevertheless, the spot check revealed that it is possible to review university degree programs outside Europe by applying the indicator system introduced here. Although there is no representativity in these results (Figure 3), there is quite some ESD identifiable in the investigated degree programs: The five international ME bachelor 


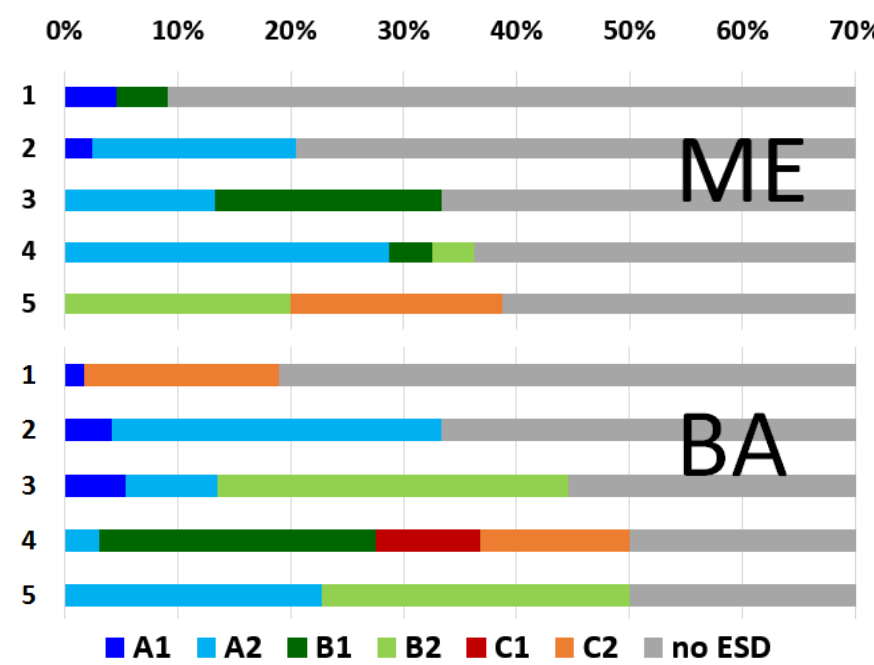

Figure 3. Quantification of ESD (\%) at universities outside Germany. Sorted by ascending numbers (totals). Data refer to information valid at start of academic year 2017/18. The indicators A1-C2 refer to Table 1. Examined degree programs and universities are specified in the supplement Table S2. ME = mechanical engineering, $\mathrm{BA}=$ business administration. ESD = education for a sustainable development

programs contain $27.6 \% \mathrm{ESD}$, on average, compared to $15.0 \% \mathrm{ESD}$ included in the analogous 22 German ME bachelor programs (on average, universities and universities of Applied Sciences taken together). On the other hand, if just mandatory classes (A1-B1-C1) are considered, this reduces to $7.1 \%$ internationally (Figure 3), compared to $5.4 \%$ found in the 22 German bachelor degree programs related to ME. Also, only one of the reviewed international universities offers a considerable amount of compulsory ESD classes in an undergraduate ME program, which is the University of California in Berkeley (No. 3 in Figure 3, top). This can be attributed to the fact that at US universities interdisciplinary courses are traditionally part of academic education, in this case specifically classes in humanities, social sciences and foreign languages.

The reviewed international BA bachelor programs revealed much higher ESD contents (Figure 3), compared to their counterparts in Germany (Figure 1). We found an average of $39.4 \%$ when all ESD classes are considered (Figure 3), versus $29.4 \%$ at the 32 programs reviewed in Germany (Figure 1). When only looking at compulsory courses, this shrinks to $9.0 \%$ dedicated to ESD internationally (Figure 3), compared to $6.0 \%$ of such classes in the analogous German programs (Figure 1).

These results are relativized by the fact that four of the international universities reviewed for ESD contents of their bachelor programs here (University of California Berkeley, ETH Zurich, National University of Singapore, Australian National University) are grouped among the "Top 10 Universities Taking the Lead on Sustainability" (EcoWatch, 2018), an evaluation system that is, however, focussed on management instead of educational aspects.

\section{Quantifying ESD across a Single University's Range of Offered Degree Programs and Time Trend Identification}

The analytical methodology presented here has been as well applied on the degree programs of the UmweltCampus Birkenfeld for the winter term 2017/18. The campus, a part of the University of Applied Sciences Trier, founded in the year 1996 and dedicated to environmentally related research and education (Umwelt-Campus, 2018), can be expected to offer a particularly high number of ESD subjects. Recently, there were 2,400 students enrolled at this campus (Umwelt-Campus, 2019). In the term 2017/18 it offered 16 bachelor degree programs and 12 master degree programs (Figure 4). We did not consider the dual education tracks in our analysis (industry elements cannot be assessed for ESD) reducing the number of bachelor degree programs considered to 11. 


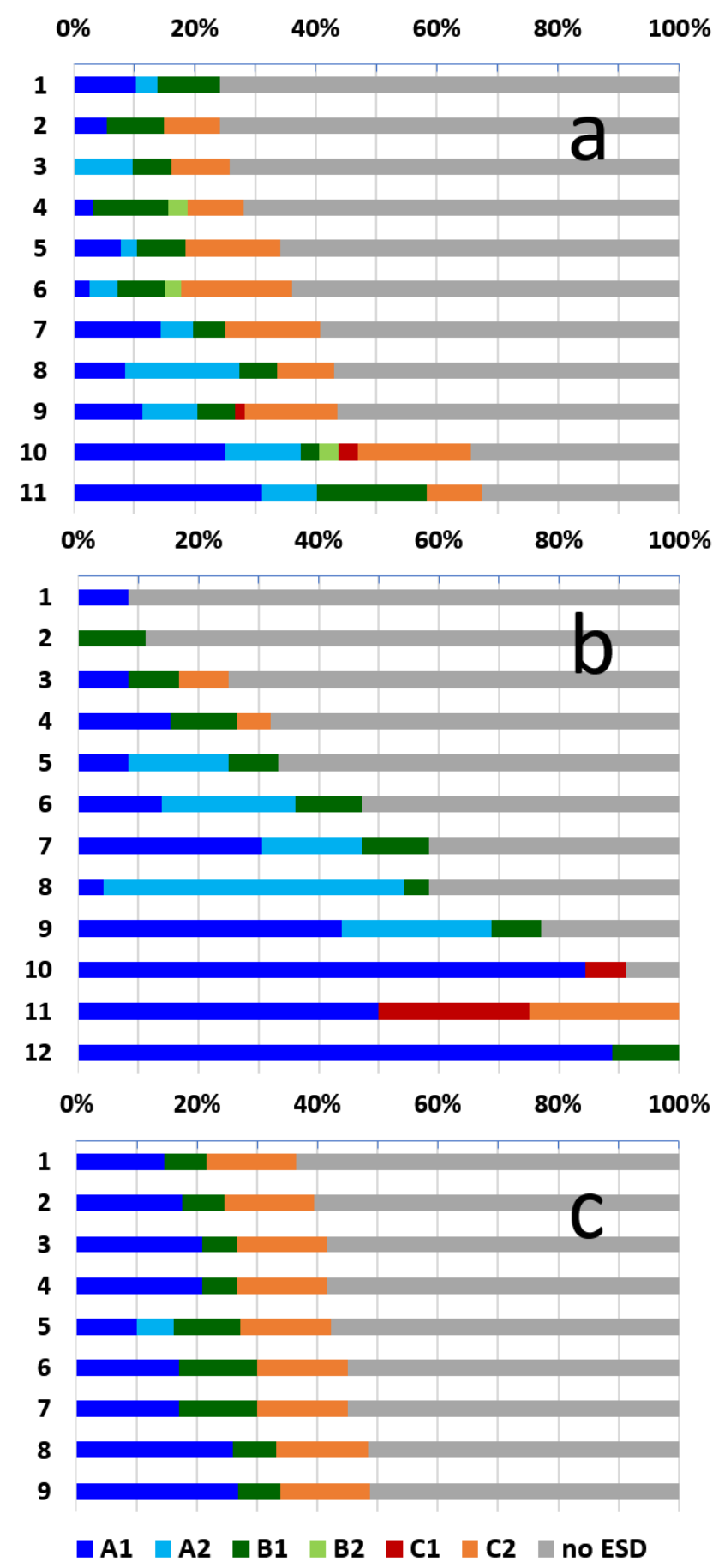

Figure 4. Quantification of ESD (\%) in degree programs of Umwelt-Campus Birkenfeld, University of Applied Sciences Trier (1999 - 2017/18), sorted by bachelor programs (a) and master programs (b) in winter term 2017/18. The initial degree programs the campus offered in 1999 based on diploma degrees which were analysed as well (c). Degree programs sorted by ascending numbers each (totals). The indicators A1-C2 refer to Table 1 . Examined degree programs are specified in the supplement Table S3. In brief: a5/6/ - b3/5 - c1/2 Computer Science; a3 b2 - c5 (ME); a2 physics; a1 - b4 - c6/7 process engineering; a10 - b9 - c3 BA; a8 - b7 - c8/9 business \& engineering, a9 - b1/8 - c4 law; a4 biotechnology; a11 renew. energies; b10/11/12 interdisciplinary studies. ESD $=$ education for a sustainable development

In the year 1999, three years after the Umwelt-Campus started to operate, and prior to the introduction of bachelor and master degrees throughout Europe in the course of the Bologna Process (Neugebauer 2015), nine diploma degree programs were offered at this campus. These were partly identical degree programs but with different focus areas (Figure 4, see also supplement Table S3).

Noticeably, the 1999 degree programs at Umwelt-Campus Birkenfeld were quite similar in structure to each other (Figure 4c), which is due to the fact that these degree programs were sharing a considerable number of classes. This way, a comprehensive interdisciplinarity and a high share of ESD in education was implemented. This 


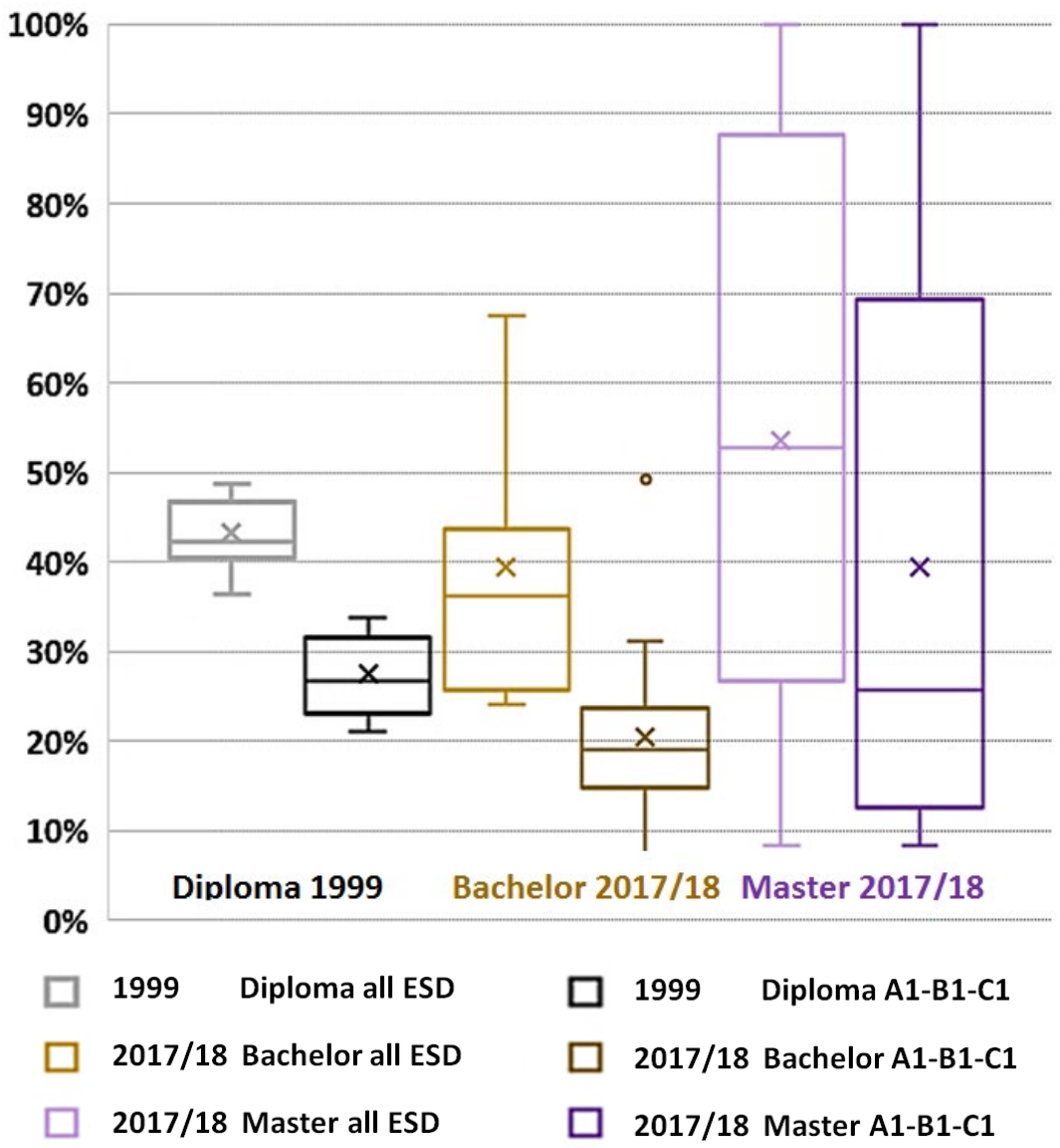

Figure 5. Temporal evolution of ESD contents (\%) within degree programs at Umwelt-Campus Birkenfeld (University of Applied Sciences Trier) over 18 years, based on the data from Figure 3. Dark colours: compulsory classes only, light colours: all classes considered. The indicators A1-B1-C1 refer to Table 1. ,all” = indicators A1C2. ESD = education for a sustainable development

is an attempt successfully applied currently at Leuphana University of Lüneburg, where students from different degree programs in the first semesters are collected for introductory interdisciplinary and sustainability-related classes, this way reaching a very high percentage of ESD across degree programs (Hoffmann, 2017). At UmweltCampus Birkenfeld, however, this integrating concept was increasingly abandoned after 1999 resulting in a more heterogeneous degree program pattern today (Figure 4, a+b). In 1999, for example, every student had the opportunity to opt for a foreign semester without loss of time (Figure 4c, indicator level C2). Later on, when switching from diploma to the bachelor/master system, this "practical semester" was partly removed from degree programs. Foreign semesters which increase the time of studying at the home university are not considered, of course, because almost all students everywhere can be on leave for a foreign semester spending additional life time and money. Such opportunities are not encouraging more students to go abroad and thus amend their personal ESD horizon.

The boxplot analysis visualizes the diversification of degree programs in the history of this campus (Figure 5). Relatively uniform 4-years diploma degree programs from the foundation time in 1999 were replaced by a high number of 3-years bachelor's degrees as well as consecutive 2-years master's programs. The variability in ESD percentage increases significantly from diploma/bachelor to master: At the master's degree level, there are, on the one hand, degree programs like insolvency law and mechanical engineering (digital products) with less than $12 \%$ of ESD. On the other hand, fully interdisciplinary degree programs like International Material Flow Management and Sustainable Change attain scores at around $100 \%$ of ESD (Figure 4b, b10-b12).

It is also interesting to analyse the general trend in ESD averages when switching from diploma to bachelor/master at Umwelt-Campus Birkenfeld (Figure 5): When all ESD (compulsory plus elective) classes are quantified, the averaged percentage ascends moderately from $43.2 \%$ in 1999 to $46.4 \%$ in $2017 / 18$, bachelor and master programs taken together (Figure 5). Considering mandatory classes only, there is an increase from $27.5 \%$ (1999) to $30.0 \%$ (bachelor and master programs taken together, Figure 5) in the period from 1999 to 2017/18. Concluding, the campus in principle kept his ESD competence over these 18 years of observation time.

Another difference stands out when looking at the box plot analysis: When switching from the diploma degree to the bachelor/master system, a significant part of ESD was moved to the master programs: The bachelor 
programs, establishing the fundamental education, are much thinner in ESD compared to the original diploma degree programs (Figure 5).

Finally we can compare specific Umwelt-Campus ME and BA bachelor degree programs with the picture we derived from the representative analysis of those programs offered in Germany: Here the Umwelt-Campus ME bachelor (Figure 1, top right, program No 10), scores relatively well with, however, just $6.5 \%$ ESD being mandatory. As a comparison, two ME bachelor degree programs (in production technology and automation engineering) from another University campus dedicated to ESD, the Leuphana University Lüneburg, revealed over $40 \%$ of compulsory classes designated to ESD (Hoffmann, 2017), far above the programs analysed to represent Germany as a whole (Figures 1 and 2). Though, the Umwelt-Campus BA bachelor program (a10 in Figure 4a) reveals an ESD content high above the average in BA programs (Figures 1 and 2).

\section{CONCLUSIONS}

With the comprehensive indicator system presented here it is possible to quantify and to compare ESD contents of degree programs.

Primarily, the two most popular disciplines in Germany (mechanical engineering and business administration) were reviewed. These disciplines are of high, if not decisive importance in society and economy to ensure and to achieve sustainability. Graduates of these degree areas will have to shape the "great transformation" (WBGU, 2011) on the way to a viable future.

The review methodology also worked for international degree programs. The ESD contents identified this way were not found to be significantly higher than those of the respective ME and BA programs in Germany.

Finally, an essential question arises: How much ESD is enough? This question cannot be answered quantitatively. However, the analysis returned that both the German ME and BA bachelor programs contained just a minimum of ESD which cannot be unselected by the students: $5.3 \%$ (ME) versus $5.9 \%(\mathrm{BA})$, respectively. This means around every $20^{\text {th }}$ class is dealing with topics needed for society to survive in the future. Given this low percentage of ESD-related classes, there is a high probability, that, as e.g., engineering graduates may not be aware of the effects of toxic emissions the technology they deal with has on health and environment (see motivation for this study above). Also, the low percentage of compulsory classes in ESD must be seen in the light of the comprehensive enumeration of ESD indicators suggested here: Although applying a broad ESD definition, we resulted in low percentages of ESD in degree programs, when it comes to compulsory classes. Accordingly, we would suggest to increase the amount of ESD taught at universities. The feasability is demonstrated by the high ESD contents in a few BA degree programs, such as the one at Umwelt-Campus Birkenfeld, and as well highly ESD containing ME bachelor programs at Leuphana University of Lüneburg.

There are also fully interdisciplinary master courses to be found that are focussed up to $100 \%$ on ESD, like those at Umwelt-Campus Birkenfeld. Together with a high number of electives in ESD identified particularly at BA degree programs in Germany, this is encouraging. However, ESD should be built much better into the fundamentals of teaching, into bachelor programs (instead of primarily into master programs), into compulsory classes (instead of just into electives), and into established degree programs like BA and ME (instead of mainly into new hybrid interdisciplinary degree programs).

In Germany a (partial) switch to English language university education would be helpful, since the majority of the scientific discourse takes place in English. Integrating this language into the mandatory part of degree programs will make it significantly easier for graduates to begin partaking in the international discourse.

The relatively large autonomy of many higher education institutions would, on the one hand, allow for the direct integration of sustainability classes (Kapitulcinová et al., 2018). On the other hand, in practise, it may often act as a barrier because a traditional mono-disciplinary perception of certain disciplines prevents a fast implementation of ESD in the interest of keeping traditions and independence.

UNESCO (2019) "aims to improve access to quality education on sustainable development at all levels and in all social contexts". It seems there is still a long way to go.

\section{ACKNOWLEDGEMENT}

We are grateful to Viola Helmers for comments on this manuscript. 


\section{REFERENCES}

Adomßent, M., Fischer, D., Godemann, J., Herzig, C., Otte, I., Rieckmann, M. and Timm, J. (2014). Emerging areas in research on higher education for sustainable development e management education, sustainable consumption and perspectives from Central and Eastern Europe. Journal of Cleaner Production, 62, 1-7.

Archer, G. (2016). Dieselgate: Who? What? How? A study by Transport \& Environment, September 2016. 30 pp. Retrieved on August 14, 2018 from https://www.transportenvironment.org/sites/te/files/downloads/ 2016_09_Dieselgate_report_who_what_how_FINAL.pdf

Berzosa, A., Bernaldo, M. O. and Fernandez-Sanchez, G. (2017). Sustainability assessment tools for higher education: An empirical comparative analysis. Journal of Cleaner Production, 161, 812-820 https://doi.org/10.1016/j.jclepro.2017.05.194

Cambridge University. (2018). International Student Office. Information for Colleges, Faculties and Departments. Retrieved on January 11, 2018 from https://www.iso.admin.cam.ac.uk/erasmus-plus/colleges-facultiesdepartments

Caradonna, J. L. (2014). Sustainability: A history. Oxford University Press, 330 pp.

Dalrymple, J. and Miller, W. (2006). Interdisciplinarity: a key for real-world learning. Planet, (17), 29-31. https://doi.org/10.11120/plan.2006.00170029

Degraeuwe, B. and Weiss, M. (2017). Does the New European Driving Cycle (NEDC) really fail to capture the $\mathrm{NO}_{\mathrm{x}}$ emissions of diesel cars in Europe? Environmental Pollution, 222, 234-241 https://doi.org/10.1016/j.envpol.2016.12.050

Disterheft, A., Caeiro, S., Azeiteiro, U. M. and Leal Filho, W. (2013). Sustainability Science and Education for Sustainable Development in Universities: A Way for Transition. In S. Caeiro et al. (eds.), Sustainability Assessment Tools in Higher Education Institutions, pp 3-26. https://doi.org/10.1007/978-3-319-02375-5_1

EcoWatch. (2018). Top 10 Universities Taking the Lead on Sustainability. Internet presentation, Dec. 17, 2014. Retrieved on December 30, 2018 from https://www.ecowatch.com/top-10-universities-taking-the-lead-onsustainability-1881990599.html

Figueiro, P. S. and Raufflet, E. (2015). Sustainability in higher education: a systematic review with focus on management education. Journal of Cleaner Production, 106, 22-33. https://doi.org/10.1016/j.jclepro.2015.04.118

German Council for Sustainable development. (2018). Der hochschulsperifische Nachbaltigkeitskodex. Brochure, 8 pp. Retrieved on August 11, 2018 from https:/ /www.deutscher-nachhaltigkeitskodex.de/fileadmin/user_upload/ dnk/dok/leitfaden/20180509_Deutscher_Nachhaltigkeitskodex_Hochschulen.pdf

Glavič, P. and Lukman, R. (2007). Review of sustainability terms and their definitions. Journal of Cleaner Production, 15(18): 1875-1885. https://doi.org/10.1016/j.jclepro.2006.12.006

Godemann, J., Haertle, J., Herzig, C. and Moon, J. (2014). United Nations supported Principles for Responsible Management Education: purpose, progress and prospects. Journal of Cleaner Production, 62, 16-23. https://doi.org/10.1016/j.jclepro.2013.07.033

Haan, G. and de Harenberg, D. (1999). Bildung für eine nachhaltige Entwicklung. Gutachten zum Programm. Bonn : BLK 1999, 108 S. - (Materialien zur Bildungsplanung und zur Forschungsförderung). Retrieved on August 14, 2018 from http://www.blk-bonn.de/papers/heft72.pdf

Haigh, M. (2008). Internationalisation, planetary citizenship and Higher Education Inc. Compare: A Journal of Comparative and International Education, 38(4) 427-440. https:/ / doi.org/10.1080/03057920701582731

Harrison, G. P., McPherson, D. E. and Williams, D. A. (2007). Promoting interdisciplinarity in engineering teaching. European Journal of Engineering Education, 32(3), 285-293. https://doi.org/10.1080/03043790701276775

Helling, K. (2018). Environmental Campus Birkenfeld-A Role Model for Universities on How to Contribute to the Implementation Process of the Sustainable Development Goals. In: Leal Filho W. (eds) Handbook of Sustainability Science and Research. World Sustainability Series. Springer, Cham

Hochschulkompass.de (2018). Search engine of the German Rector's conference. Retrieved on October 4, 2018 from https://www.hochschulkompass.de/home.html

Hoffmann, I. (2017). Nachhaltigkeit in der Hocbschullebre am Umwelt-Campus Birkenfeld. Abschlussarbeit zur Erlangung des akademischen Grades Bachelor of Science, Fachbereich Umweltplanung/Umwelttechnik, Umwelt-Campus Birkenfeld der Hochschule Trier. 132 pp.

Holm, T., Sammalisto, K., Grindsted, T. S. and Vuorisalo, T. (2015). Process framework for identifying sustainability aspects in university curricula and integrating education for sustainable development. Journal of Cleaner Production, 106(2015), 164-174. https://doi.org/10.1016/j.jclepro.2015.04.059

Jones, P., Trier, C. J. and Richards, J. P. (2008). Embedding Education for Sustainable Development in higher education: A case study examining common challenges and opportunities for undergraduate programmes. International Journal of Educational Research, 47, 341-350. https:// doi.org/10.1016/j.ijer.2008.11.001 
Kapitulcinová, D., AtKisson, A., Perdue, J. and Will, M. (2018). Towards integrated sustainability in higher education e Mapping the use of the Accelerator toolset in all dimensions of university practice. Journal of Cleaner Production, 172, 4367-4382. https:// doi.org/10.1016/j.jclepro.2017.05.050

Karatzoglou, B. (2013). An in-depth literature review of the evolving roles and contributions of universities to Education for Sustainable Development. Journal of Cleaner Production, 49, 44-53. https://doi.org/10.1016/j.jclepro.2012.07.043

Khalili, N. R., Duecker, S., Ashton, W. and Chavez, F. (2015). From cleaner production to sustainable development: the role of academia. Journal of Cleaner Production, 96, 30-43 https://doi.org/10.1016/j.jclepro.2014.01.099

Klaassen, R. G. (2018). Interdisciplinary education: a case study. European Journal of engineering education, 43(6), 842 859. https://doi.org/10.1080/03043797.2018.1442417

KMK. (2018). Rahmenprüfungsordnungen/Fachspezifische Bestimmungen. Internet page. Retrieved on August 20, 2018 from https://www.kmk.org/themen/hochschulen/studium-und-pruefungen/rahmenpruefungsord nungen.html

Lozano, R., Ceulemans, K., Alonso-Almeida, M., Huisingh, D., Lozano, F. J., Waas, T., Lambrechts, W., Lukman, R. and Hugé, J. (2015). A review of commitment and implementation of sustainable development in higher education: results from a worldwide survey. Journal of Cleaner Production, 108, 1-18. https://doi.org/10.1016/j.jclepro.2014.09.048

Mulder, K. F. (2017). Strategic competences for concrete action towards sustainability: An oxymoron? Engineering education for a sustainable future. Renewable and Sustainable Energy Reviews, 68, 1106-1111. https://doi.org/10.1016/j.rser.2016.03.038

Neugebauer, M. (2015). The Introduction of Bachelor Degrees and the Under-representation of Students from Low Social Origin in Higher Education in Germany: A Pseudo-Panel Approach. European Sociological Review, 31(5)1, 591-602. https://doi.org/10.1093/esr/jcv061

Ramos, T. B., Caeiro, S., van Hoof, B., Lozano, R., Huisingh, D. and Ceulemans, K. (2015) Experiences from the implementation of sustainable development in higher education institutions: Environmental Management for Sustainable Universities. Journal of Cleaner Production, 106, 3-10. https://doi.org/10.1016/j.jclepro.2015.05.110

Scott, L. M. (2013). Does Science need a global language? University of Chicago Press (May 6, 2013). 240 pages.

Siemer, S. H., Rammel, C. and Elmer, S. (2006). Pilotstudie zu Indikatoren einer Bildung für nachhaltige Entwicklung. Erstellt im Auftrag des Zukunftsministeriums, Lüneburg / Wien, im Juni 2006. 153 pp. Retrieved on December 30, 2018 from https:/ /bildung.bmbwf.gv.at/schulen/unterricht/ba/bine.html

Statistisches Bundesamt. (2016). Bildung und Kultur. Studierende an Hochschulen. Wintersemester 2015/2016. Fachserie 11. Statistisches Bundesamt. Wiesbaden (Reihe 4.1). Retrieved on April 22, 2017 from https://www.destatis.de/DE/Publikationen/Thematisch/BildungForschungKultur/Hochschulen/Studieren deHochschulenEndg2110410167004.pdf?__blob=publicationFile

Stough, T., Ceulemans, K., Lambrechts, W. and Cappuyns, V. (2018). Assessing sustainability in higher education curricula: A critical reflection on validity issues. Journal of Cleaner Production, 172, 4456-4466. https:// doi.org/10.1016/j.jclepro.2017.02.017

Togo, M. and LotzSisitka, H. (2009). Unit Based Sustainability Assessment Tool. A resource book to complement the UNEP Mainstreaming Environment and Sustainability in African Universities Partnership. Howick, ShareNet. Retrieved on December 30, 2018 from http://wedocs.unep.org/bitstream/handle/20.500.11822/11283/ USAT_tool.pdf? sequence $=1$ \&isAllowed $=\mathrm{y}$

Umweltbundesamt (2018). Unterschied zwischen Außenluft- und Arbeitsplatzgrenzwert für $\mathrm{NO}_{2}$. Retrieved on August 13, 2018 from https://www.umweltbundesamt.de/themen/unterschied-zwischen-aussenluft

Umwelt-Campus (2018). Green-Campus-Concept. Internet presentation of Umwelt-Campus Birkenfeld, University of Applied Sciences Trier. Retrieved from https://www.umwelt-campus.de/en/campus/life-on-campus/greencampus-concept/

Umwelt-Campus (2019). Willkommen am Umwelt-Campus Birkenfeld. Internet presentation of Umwelt-Campus Birkenfeld, University of Applied Sciences Trier. Retrieved on January 1, 2019 from https://www.umweltcampus.de/

UN (2018) Sustainable development knowledge platform. Sustainable development goals. Retrieved on August 14, 2018 from https://sustainabledevelopment.un.org/sdgs

UNECE (2006) Indicators for education for sustainable development. Economic commission for Europe, Committee on environmental policy. UNECE Steering Committee on Education for Sustainable Development. Addendum from the second meeting in Geneva, 4-5 December 2006, Item 3 of the provisional agenda. ECE/CEP/AC.13/2006/5/Add.1, 31 July 2006. 19 pp, see Annex 1(a). Retrieved on August 14, 2018 from https://www.bmb.gv.at/schulen/unterricht/ba/bine_unece_indicators_26961.pdf?4dzgm2 
UNESCO (2005). UN Decade of Education for Sustainable Development 2005 - 2014. The DESD at a glance. 10 pp. Retrieved on August 11, 2018 from http://unesdoc.unesco.org/images/0014/001416/141629e.pdf

UNESCO (2009). A review of education of sustainable development policies from a cultural diversity and intercultural dialogue perspective intentifying opportunities for future action. A review, 52 pp. http://unesdoc.unesco.org/images/0021/002117/211750e.pdf August 20, 2018

UNESCO (2011). Hochscbulen für eine nachbaltige Entwicklung. Nachhaltigkeit in Forschung, Lehre und Betrieb. German UNESCO commission e.V. 73 pp. Retrieved on August 12, 2018 from https://www.hrk.de/uploads/media/Hochschulen_fuer_eine_nachhaltige_Entwicklung_Feb2012.pdf

UNESCO (2012). Education for Sustainable Development. Sourcebook, 51 pp. Retrieved on August 14, 2018 from http://unesdoc.unesco.org/images/0021/002163/216383e.pdf

UNESCO (2017). Education for Sustainable Development Goals: Learning Objectives. Report, 67 pp. Retrieved on August 20, 2018 from http://unesdoc.unesco.org/images/0024/002474/247444e.pdf

UNESCO (2018). Global Action Programe on Education for Sustainable development. Information folder, 25 pp. Retrieved on August 11, 2018 from http://unesdoc.unesco.org/images/0024/002462/246270E.pdf

UNESCO Germany (2018). Education for Sustainable Development in Germany. Retrieved on August 11, 2018 from https://www.bne-portal.de/en/education-sustainable-development-germany

UNESCO (2019). Education for Sustainable Development. Internet presentation. Retrieved on January 1, 2019 from https://en.unesco.org/themes/education-sustainable-development

Wals AEJ (2014) Sustainability in higher education in the context of the UN DESD: a review of learning and institutionalization processes. Journal of Cleaner Production, 62, 8-15 https://doi.org/10.1016/j.jclepro.2013.06.007

WBGU (2011) World in transition. A social contract for sustainability flagship report. German Advisory Council on Global Change (WBGU). 420 pp. Retrieved on 30 April 2018 from http://www.wbgu.de/fileadmin/ templates/dateien/veroeffentlichungen/hauptgutachten/jg2011/wbgu_jg2011_en.pdf

Weijen D van (2012). The Language of (Future) Scientific Communication Retrieved on August 20, 2018 from https://www.researchtrends.com/issue-31-november-2012/the-language-of-future-scientific-communication 


\section{SUPPLEMENT}

Table S1. Examined German universities (analogue to Figure 1). Date of documents retrieval: 10-12/2017

\begin{tabular}{|c|c|c|c|}
\hline \multicolumn{4}{|c|}{ ME Mechanical Engineering (Bachelor) } \\
\hline 1 & Technische Universität Dortmund & 1 & Technische Hochschule Mittelhessen, Campus Friedberg \\
\hline 2 & Universität Hannover & 2 & Technische Hochschule Mittelhessen, Campus Gießen \\
\hline 3 & Universität Duisburg-Essen, Campus Duisburg & 3 & Hochschule Pforzheim \\
\hline 4 & Technische Universität Darmstadt & 4 & Hochschule Düsseldorf \\
\hline 5 & Technische Universität Braunschweig & 5 & Frankfurt University of Applied Sciences \\
\hline 6 & Technische Universität Hamburg-Harburg & 6 & Hochschule Trier - Campus Trier \\
\hline 7 & Universität Stuttgart & 7 & Hochschule RheinMain \\
\hline 8 & Ruhr-Universität Bochum & 8 & Fachhochschule Südwestfalen, Campus Soest \\
\hline 9 & Rheinisch-Westfälische Technische Hochschule Aachen & 9 & Fachhochschule Südwestfalen, Campus Meschede \\
\hline 10 & Technische Universität München & 10 & Hochschule Trier - Umwelt-Campus Birkenfeld \\
\hline 11 & Technische Universität Berlin & 11 & Fachhochschule Dortmund \\
\hline \multicolumn{4}{|c|}{ BA Business Administration (Bachelor) } \\
\hline 1 & Universität Trier & 1 & $\begin{array}{l}\text { Hochschule für Technik, Wirtschaft und Medien } \\
\text { Offenburg }\end{array}$ \\
\hline 2 & Freie Universität Berlin & 2 & Hochschule Ostwestfalen-Lippe \\
\hline 3 & Universität Duisburg-Essen; Campus Duisburg & 3 & Hochschule Wismar - University of Applied Sciences: \\
\hline 4 & Universität des Saarlandes & 4 & Frankfurt University of Applied Sciences \\
\hline 5 & RWTH Aachen & 5 & $\begin{array}{l}\text { Hochschule Landshut - Hochschule für angewandte } \\
\text { Wissenschaften }\end{array}$ \\
\hline 6 & Universität Regensburg & 6 & Ostbayerische Technische Hochschule Regensburg \\
\hline 7 & Universität Siegen & 7 & Hochschule Düsseldorf \\
\hline 8 & Heinrich-Heine-Universität Düsseldorf & 8 & $\begin{array}{l}\text { Hochschule für angewandte Wissenschaften Würzburg- } \\
\text { Schweinfurt }\end{array}$ \\
\hline 9 & Westfälische Wilhelms-Universität Münster & 9 & Hochschule für angewandte Wissenschaften Kempten \\
\hline 10 & Universität zu Köln & 10 & Fachhochschule Dortmund \\
\hline 11 & Philipps-Universität Marburg & 11 & Fachhochschule Kiel \\
\hline 12 & Universität Duisburg-Essen; Campus Essen & 12 & $\begin{array}{l}\text { Technische Hochschule Mittelhessen - THM Campus } \\
\text { Gießen }\end{array}$ \\
\hline 13 & Universität Bremen & 13 & Hochschule Mainz \\
\hline 14 & Universität Passau & 14 & $\begin{array}{l}\text { Hochschule für Wirtschaft und Umwelt Nürtingen- } \\
\text { Geislingen }\end{array}$ \\
\hline 15 & Georg-August-Universität Göttingen & & \\
\hline 16 & Humboldt-Universität zu Berlin & & \\
\hline 17 & Katholische Universität Eichstätt-Ingolstadt & & \\
\hline 18 & Universität Mannheim & & \\
\hline
\end{tabular}

Table S2.International degree programs examined for ESD in mechanical engineering (ME) and business administration (BA). Date of documents retrieval: 11-12/2017

\begin{tabular}{cll}
\hline No & University & Degree program \\
\hline ME1 & Chalmers University of Technology, Gothenburg, Sweden & Maskinteknik, Bachelor \\
\hline ME2 & Delft University of Technology, The Netherlands & (B.Sc.) Mechanical Engineering \\
\hline ME3 & University of California, Berkeley, USA & (Undergraduate Studies) Mechanical Engineering \\
\hline ME4 & University of Cambridge, England & (B.A.) Engineering \\
\hline ME5 & Eidgenössische Technische Hochschule (ETH) Zürich & (B.Sc.) Maschineningenieurwissenschaften \\
\hline \multirow{2}{*}{ BA1 } & $\begin{array}{l}\text { University of Amsterdam, College of Economics and Business, } \\
\text { The Netherlands }\end{array}$ & (B.Sc.) Business Administration \\
\hline \multirow{2}{*}{ BA2 } & $\begin{array}{l}\text { Australian National University, College of Business and } \\
\text { Economics, Canberra }\end{array}$ & Bachelor of Business Administration (BBA) \\
\hline BA3 & National University of Singapore & Bachelor of Business Administration (BBA) \\
\hline BA4 & Universität St. Gallen, Switzerland & (B.A.) Betriebswirtschaftslehre \\
\hline BA5 & Heriot Watt University, Edinburgh, Scotland & Bachelor of Business Administration (BBA) \\
\hline
\end{tabular}


European Journal of Sustainable Development Research, 3(4), em0092

Table S3. Examined degree programs (analogue to Figure 3) at Umwelt-Campus Birkenfeld (University of Applied Sciences Trier). These are degree programs taught in German language (except the two master degree programs in International material flow management, which are taught in English). The English translations of the program titles are given here for information. Date of documents retrieval: 10-12/2017 (1999 degree program information taken from printed university publications from that year)

Bachelor's degree programs at Umwelt-Campus Birkenfeld, University of Applied Sciences Trier (Winter term 2017/18)

\begin{tabular}{|c|c|c|}
\hline No & Degree program & English translation \\
\hline a1 & Bio-, Umwelt- und Prozess-Verfahrenstechnik (6 Semester) & (bio)process engineering (6 semester) \\
\hline a2 & Physikingenieurwesen & engineering physics \\
\hline a3 & Maschinenbau & mechanical engineering \\
\hline a4 & Bio- und Pharmatechnik & Biotechnology \& pharmaceutical engineering \\
\hline a5 & Medieninformatik & media computer science \\
\hline a6 & Angewandte Informatik & Applied computer science \\
\hline a7 & Umwelt- und Wirtschaftsinformatik & Environmental \& business informatics \\
\hline a8 & Wirtschaftsingenieurwesen / Umweltplanung & business administration and engineering \\
\hline a9 & Wirtschafts- und Umweltrecht & business and environmental law \\
\hline a10 & Umwelt- und Betriebswirtschaft & business administration \\
\hline a11 & Erneuerbare Energien & renewable energies \\
\hline \multicolumn{3}{|c|}{ Master's degree programs at Umwelt-Campus Birkenfeld, University of Applied Sciences Trier (Winter term 2017/18) } \\
\hline $\mathrm{b} 1$ & Insolvenzrecht und Reorganisationsverfahren & insolvency law \\
\hline $\mathrm{b} 2$ & Digitale Produktentwicklung - Maschinenbau & mechanical engineering (digital products) \\
\hline b3 & Medieninformatik & media computer science \\
\hline $\mathrm{b} 4$ & Bio- und Prozessverfahrenstechnik & (bio)process engineering \\
\hline b5 & Angewandte Informatik & Applied computer science \\
\hline $\mathrm{b} 6$ & Umweltorientierte Energietechnik & energy engineering \\
\hline $\mathrm{b} 7$ & Wirtschaftsingenieurwesen & business administration and engineering \\
\hline $\mathrm{b} 8$ & Unternehmensrecht und Energierecht & Business and energy law \\
\hline b9 & Umwelt- und Betriebswirtschaft & business administration \\
\hline $\mathrm{b} 10$ & \multicolumn{2}{|c|}{ International Material Flow Management (Master of Engineering) } \\
\hline $\mathrm{b} 11$ & \multicolumn{2}{|l|}{ International Material Flow Management (Master of Science) } \\
\hline $\mathrm{b} 12$ & Vom Wissen zum Handeln & Sustainable Change \\
\hline \multicolumn{3}{|c|}{ Diploma degree programs at Umwelt-Campus Birkenfeld, University of Applied Sciences Trier (1999) } \\
\hline $\mathrm{c} 1$ & Angewandte Informatik/Umweltstatistik & Appl. comp. science (environ. statistics) \\
\hline $\mathrm{c} 2$ & Angewandte Informatik/Umweltsimulation & Appl. comp. science (environ. simulation) \\
\hline $\mathrm{c} 3$ & Umwelt- und Betriebswirtschaft & business administration \\
\hline $\mathrm{c} 4$ & Wirtschafts- und Umweltrecht & business and environmental law \\
\hline c5 & Maschinenbau & mechanical engineering \\
\hline c6 & Entsorgungstechnik/Abfallbehandlung & disposal engineering (waste management) \\
\hline c7 & Entsorgungstechnik/Altlastensanierung & disposal engineering (remediation) \\
\hline $\mathrm{c} 8$ & Wirtschaftsingenieurwesen/ Abfallwirtschaft & $\begin{array}{l}\text { business administration and engineering (waste } \\
\text { management) }\end{array}$ \\
\hline c9 & Wirtschaftsingenieurwesen/Ökologische Planung & $\begin{array}{l}\text { business administration and engineering (ecological } \\
\text { planning) }\end{array}$ \\
\hline
\end{tabular}

